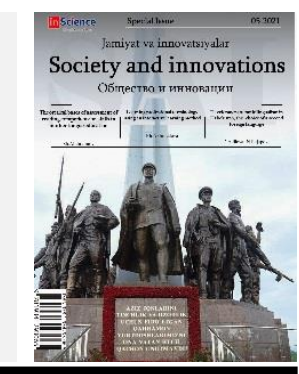

\title{
Approaches to teaching writing in efl classes
}

\section{Koldigiz MIRZAYEVA ${ }^{1}$}

Tashkent State University of Uzbek Language and Literature

\begin{tabular}{l} 
ARTICLE INFO \\
\hline Article history: \\
Received April 2021 \\
Received in revised form \\
20 April 2021 \\
Accepted 15 May 2021 \\
Available online \\
25 June 2021
\end{tabular}

\section{Keywords:}

writing, approach,

grammar, syntax,

a blank piece of paper,

majority, boring,

success, idea,

words, stages,

message,

communicate, mistake,

free composition.

\begin{abstract}
As the title implies the article describes the benefits of different approaches in teaching writing through different types of activities and methods. The aim of the article is to provide the reader with some material on organizing the writing lesson effectively. Variety types of useful activities of teaching writing skill are emphasized in the article.
\end{abstract}

\section{1-1415/C) 2021 in Science LLC.}

This is an open access article under the Attribution 4.0 International (CC BY 4.0) license (https://creativecommons.org/licenses/by/4.0/deed.ru)

\section{Ingliz tili xorijiy til sifatida o'qitiladigan (EFL) sinflarda yozish ko'nikmasini o'qitish usullari}

\author{
Kalit so'zlar: \\ yozuv, \\ yondashuv, \\ grammatika, \\ sintaksis, \\ toza oq qog'oz, \\ ko'pchilik, \\ zerikarli, \\ muvaffaqiyat, g'oya, \\ so'zlar, bosqichlar, \\ xabar, muloqot, \\ xato, erkin bayon.
}

\begin{abstract}
ANNOTATSIYA
Sarlavhada ta'kidlanganidek, maqolada turli xil mashq va uslublar orqali yozish ko'nikmasini o'rgatishda turli xil yondashuvlarning afzalliklari tasvirlangan. Maqolaning maqsadi o'quvchiga yozish ko'nikmasi darsini samarali tashkil etish bo'yicha bir qancha materiallarni taqdim etishdir. Maqolada yozish mahoratini o'rgatish uchun foydali bo'lgan topshiriqlarning xilma-xil turlariga urg'u berilgan.
\end{abstract}

\footnotetext{
${ }^{1}$ Senior lecturer, Tashkent State University of Uzbek Language and Literature. Tashkent, Uzbekistan. E-mail: mirzayevaxolida9@gmail.com.
} 


\section{Подходы к обучению письменности в классах EFL (английский как иностранный)}

Ключевые слова:
письмо,
подход,
грамматика,
синтаксис,
чистый лист бумаги,
большинство,
скучность,
успех,
идея,
слова,
этапы,
сообщение,
общение,
ошибка,
свободное сочинение.

АННОТАЦИЯ

Как следует из названия, в статье описываются
преимущества различных подходов к обучению письму с
помощью различных видов деятельности и методов. Цель
статьи - предоставить читателю некоторый материал по
эффективной организации урока письма. В статье
выделены разнообразные виды полезных занятий по
обучению навыкам чтения.

Writing is one of the most complicated skill, as well as, quit interesting aspect among four skills that demands creation, imagination, and hard work from writing process to producing. A well-known English lecturer George Clan in Oxford University defined that "Writing is the activity of marking coherent words on paper and composing text. It is the vital means of communication within an organization". In fact, a survey goes on to say that $30 \%$ of our work is accomplished through written communication. Therefore, the skills of writing are essential for achieving career and business goals.

Writing is a skill that has not been accorded the attention, it deserves in high school education. It's clear that a majority of students' in high school dislike writing. When faced with a writing task, they will react with a comment like "oh no, this is so boring". To prevent this, the teacher should consider what students actually mean when they say "this is so boring", and the possibility that students are actually expressing their insecurity and lack of confidence in completing the task.

There are three stages in teaching writing. The first stage that students must go through is that of "coming to terms with reality". It is very important that students should be made aware of what their actual level of writing is at present. At this stage, teachers must not tell students what they believe their level to be but must provide the right feedback to enable students to see for themselves. Students who do not write well, should not be fooled into believing that they do. At this stage, commenting only on the positive aspects of a student paper will only create a false sense of confidence in the student. Comments on how to improve poor areas in writing both on paper and in person can help students understand just what their writing needs. Once, this stage has been satisfactorily completed then the teacher must move on to reassure students that it will be possible to improve their writing. The second stage is reassurance, itis the stage where students are made to understand that poor writing is not a curse, can be improved and most of all is not something for which they should punish themselves. The message given by the teacher should be "let's deal with it!" and this message is a crucial element in the students' writing process, because in this stage students need an external motivator. The third stage is motivation which is probably the longest stage in writing. Tasks, which allow students to narrow down their expectations and move step by step toward the final goal of success, will show them what they can do rather than what they can't. Each task should be set at a level higher than the previous one, thus with each task students will build confidence and become motivated to move on to the next step. 
When we learn any foreign language, we learn to communicate with other people: to understand them, talk to them, read what they have written and write to them.But the fact that people frequently have to communicate with each other in writing is not the only reason to include writingas a part of our foreignlanguage syllabus. There is an additional and very important reason: writing helps our students learn.

First, writing reinforces the grammatical structures, idioms, and vocabulary that we have been teaching our students. Second, when our students write, they also have a chance to be adventurous with the language, to go beyond what they have just learned to say, to take risks. Third, when they write, they necessarily become very involved with the new language: the effort to express ideas and the constant use of eye, hand, and brain is a unique way to reinforce learning. And they often discover something new to write or a new way of expressing their ideas. They discover a real need for finding the right word and the right sentence. The close relationship between writing and thinking makes writing a valuable part of any language course. A great deal of writing that goes on EFL lessons, especially in an elementary level, is sentence writing. Students repeat or complete given sentences to reinforce the structure, grammar, and vocabulary they have learned. They work with pattern sentences, performing substitutions or transformations.

Learning to write is not just "natural" extension of learning to speak a language. We learned to speak our first language at home without systematic instruction, whereas most of us had been taught in school how to write that same language. Many adult native speakers of a language find writing difficult. The two processes, speaking and writing are not identical. Let us look at some of the differences between speaking and writing:

1. Speech is universal; everyone acquires a native language in the first few years of life. Not everyone learns to read and write.

2. The spoken language had dialect variations. The written language generally demands standard forms of grammar, syntax, and vocabulary.

3. Speakers use their voices (pitch, stress, and rhythm) and bodies (gestures, and facial expressions), to help convey their ideas. Writers have to rely on the words on the page to express their meaning.

4. Speakers use pauses and intonation. Writers use punctuation.

5. Speakers pronounce. Writers spell.

6. Speaking is usually spontaneous and unplanned. Writing takes time. It is planned. We can go back and change what we have written.

7. A speaker speaks to a listener who is right there, nodding or frowning, interrupting or questioning. For the writer, the reader's response is either delayed or nonexistent. The writer has only one chance to convey information quite interesting and accurate enough to hold the reader's attention.

8. Speech is usually informal and repetitive. We say "What I mean is...?" or "Let me start again". But writing is more formal and compact. It progresses logically with fewer digressions and explanations.

9. Speakers use simple sentences with connecting words "and" and "but". Writers use more complex sentences, with connecting words like "however", "who", and "in addition". While, we could easily say "Her brother runs ten miles every day and is very healthy." We might write this sentence like "Her brother, who runs ten miles every day, is very healthy."

This article will concentrate on approaches to teaching writing in EFL classes, so that we should realize the following six approaches: the controlled-to-free approach; the free-writing approach; the paragraph-pattern approach; the grammar-syntax-organization approach; the communicative approach; and the process approach.

In the controlled-to-free approach, speech was primary and writing served to reinforce in that it stressed mastery of grammatical and syntactic forms. EFL teachers develop techniques to move students to towards this mastery. The controlled-to free approach in writing is sequential: students are given 
sentence exercises, then paragraphs to copy grammatically by changing questions to statements, present to past, or plural to singular. They might also change words, clauses or combine sentences. They work on given material and perform strictly prescribed operations on it. With these controlled compositions, it is easy for students to write without mistakes. Because the students have a limited opportunity to make mistakes, the teacher's job of marking papers is quickand easy. Only after reaching an upper-intermediate or advanced level of proficiency, students could write some free compositions, in which they express their ideas.

In the free-writing approach, some teachers have stressed quantity of writing rather than quality. They have approached the teaching of writing by assigning vast amounts of free writing on given topics with only minimal correction of error. The emphasis in this approach is that intermediate level students should put content and fluency first and not worry about form. To emphasize fluency even more, some EFL teachers ask their students to write freely on any topic without worrying aboutgrammar and spelling for five or ten minutes. At first, students find this very difficult. They have to resort to writing sentences like, "I can't think of anything to write". As they do this kind of writing more and more often, however, some find that they write more fluently and that putting words down on paper is not so frightening after all. The teachers don't correct these short of pieces of free writing, they simply read them and perhaps comment on the ideas the writer expressed. Some students might read their writing aloud to the class.

In the paragraph-pattern approach, students copy paragraphs, analyze the form of model paragraphs, and imitate model passages. They put scrambles sentences into paragraph order, they identify general and specific statements, they choose or invent an appropriate topic sentence, they insert or delete sentences. This approach is based on the principle that in different cultures people construct and organize their communication with each other in different ways. So even if students organize their ideas well in their first language, they still need to see, analyze, and practice the particularly English features of a piece of writing.

In the grammar-syntax-organization approach, some teachers say that writing can't be seen as composed of separate skills which are learned one by one. For instance, to write a clear set of instruction on how to operate a calculator, the writer needs more than the appropriate vocabulary. He needs the simple forms of verbs; an organizational plan based on chronology; sequence words like first, then, finally; and perhaps even sentence structures like "When ..., then...". During discussion and preparation of the task, all these are reviewed or taught for the first time. Students can see the connection between what they are trying to write and what they need to write it. This approach links the purpose of a piece of writing to the forms that are needed to convey the message.

The communicative approach stresses the purpose of a piece of writing and the audience for it. Student writers are encouraged to behave like writers in real life and to ask themselves the crucial questions about purpose and audience: Why am I writing this? and Who will read it? Traditionally, the teacher has been the audience for students' writing. Teachers, using the communicative approach, have extended the readership. They extend it to other students in the class, who not only read the piece but actually do something with it, such as respond, rewrite in another form, summarize, or make comments but not correct.

In the process approach, students need to realize that what they first put down on paper is not necessarily their finished product but just a beginning, a setting out of the first ideas, a draft. They should notexpect that the words they put on paper will be perfect right away. A student who is given the time for the process to work, along with the appropriate feedback from readers such as the teacher or other students, will discover new ideas, new sentences, and new words as he plans, writes a first draft, and revises what he has written for a second draft. Many teachers in EFL classes now give their students the 
opportunity to explore a topic fully in such prewriting activities as discussion, reading, debate, brainstorming, and list making.

The first piece of writing is not corrected and graded. The reader responds only to the ideas expressed. So in the process approach, students don't write on a given topic in a restricted time and hand in a composition for the teacher to find their errors, that is, to correct. Rather, students explore a topic through writing, showing the teacher and each other their drafts, and using what they write to read over, think about, and move them on to new ideas. Teachers who use the process approach give their students two crucial supports: time for the students to try out ideas and feedback on the content of what they write in their drafts. They find that then the writing process becomes a process of discovery for the students: discovery of new ideas and new language forms to express those ideas.

Success in writing for each studentshould be measured by individual realisticgoals set at the onset of the process. These goals should be attainable by the student given the student's capacity to write. At this stage, students should no longer be comparing their writing to those of people who have a better grasp of the art. It is also important that students understand that the level of writing they have achieved in English may not equal their ability to write in a native language. With time and effort that may be the next goal for the student to aim for. There is no one way to teach writing, but many ways. All of the approaches that mentioned above are useful for teaching writing.

In conclusion, not everyone can become a writer. However, everyone can learn to write better and well organized, flowing essays with clear language. Focusing on grammar and sentence structure is not the key to making better writers of our students. Students should be given what any writer needs, an understanding of their capacity to write, motivation, self-confidence and courage.

\section{REFERENCES:}

1. Barton L. and Sardinas C.P. (2004), North Star. Reading and Writing. Intermediate. Longman.

2. Dorothy E. Zemach, Lisa A. Ghulldu, Carlos Islam, Robyn Brinks, Lockwood Teacher's guide.

3. Dvorak, Trisha, Writing in the Foreign Language. Listening Reading and Writing: Analysis and Application. Ed. Barbara H. Wing. Middlebury, VT: Northeast Conference, 1986. - PP. 145-67.

4. Evans V. (1998). Successful Writing. Upper Intermediate. Express Publishing.

5. Flower, Linda. Problem-Solving Strategies for Writing. 2nd ed. New York: Harcourt Brace Jovanovich, 1985.

6. Jordan R.R. (2003). Academic Writing Course: Study Skills in English. Pearson Education Limited. Third Edition.

7. Osterholm, Katherine K. Writing in the Native Language. Listening Reading and Writing: Analysis and Application. Ed. Barbara H. Wing. Middlebury, VT: Northeast Conference, 1986. - PP. 117-43.

8. Raimes, Ann. Techniques in Teaching Writing. New York: Oxford, 1983.

9. White, R and V. Arndt. (1991). Process Writing, Harlow: London.

10. Zamel, Vivian. "Responding to Student Writing." TESOL Quarterly 19 (1985). PP. 79-101.

11. Niyazova G., Raupova L. Основные признаки и причины популярности детективного жанра. ОИ 2021, 2, - C. 515-524. 